\title{
Patient characteristics, Bacteriological profile \& outcome of Neonatal Sepsis: A Hospital Based Study
}

\author{
Jahan $\mathbf{N}^{1}$, Haque $Z S^{2} M^{2}$, Mannan $M^{3}{ }^{3}$, Akhter $M^{4}$, Yasmin $S^{5}$, Akter $S^{6}$, Talukdar AM $^{7}$, Dey $S^{8}$.
}

\begin{abstract}
Neonatal sepsis is a major cause of mortality and morbidity in newborn. The spectrum of bacteria which causes neonatal sepsis varies in different parts of the world. The organisms responsible for early onset and late onset sepsis are different. The objective of the study was undertaken to determine the pattern of bacterial isolates responsible for early and late onset neonatal sepsis. A prospective descriptive study over the period of one year was conducted at the Department of Neonatal Intensive care unit of Ad-din Women's Medical College and Hospital, Dhaka, Bangladesh.Organisms were isolated from $8.7 \%$ of collected blood samples. The male female ratio of culture proven sepsis was 1.7:1. More than half $(52.8 \%)$ of the evaluated neonates were preterm. \& $56.3 \%$ had low birth weight. The gram positive and gram negative bacteria accounted for $24.1 \%$ and $75.9 \%$ of the isolates respectively. Around three fourth of the neonates $(75.8 \%)$ presented with early onset sepsis, while $24.2 \%$ presented with late onset sepsis. Acinetobacter was the most common pathogen both in early onset (70\%) and late onset (30\%) sepsis. Pseudomonas (89.4\%) was the second most common pathogen in early onset sepsis. Total mortality rate was $5.7 \%$. Pre term, low birth weight and gram negative sepsis contributes majority of mortality. Gram negative organism especially Acinetobacter found to be commonest cause of sepsis. Pseudomonas was second most common but contributed highest in late onset sepsis and neonatal death due to sepsis.
\end{abstract}

CBMJ 2013 Jan: Vol-02, No-01: P: 49-54 Key words: Neonatal sepsis, neonates, gram negative bacteria, bacteriological profile, Neonatal Intensive Care Unit (NICU)

\section{Introduction}

Neonatal sepsis is defined as a disseminated disease with positive blood culture during the first month of life ${ }^{1}$, and is more common in developing countries compared with developed countries ${ }^{2}$. About four million neonatal deaths occur worldwide every year, $98 \%$ of which occur in developing countries, particularly Asia and Africa. ${ }^{3,}{ }^{4}$ Neonatal sepsis remains as an important cause of morbidity and mortality among infants in developing countries accounting for $30-50 \%$ of total death each year ${ }^{5}$. Infant mortality rate (IMR) in Bangladesh is $38 / 1000$ live birth $^{6}$, out of them about $70 \%$ of death occur in neonatal period (<28 days) and Neonatal mortality rate (NMR) is $27 / 1000$ live birth ${ }^{6}$. Neonatal sepsis contributes $36 \%$ of total death in Bangladesh$^{7}$. Neonatal sepsis has been classified as either early onset sepsis (EOS) (0-7 day of age) or late onset sepsis (LOS) (728 days of age) ${ }^{2,8}$. EOS is due to vertical transmission during labor or birth. It includes bacteremia and/or sepsis, meningitis and pneumonia. LOS is due to vertical, horizontal or nosocomial infection. Its most clinical manifestations are: meningitis (30-40\%),
1. * Dr. Nasim Jahan Assistant professor, Department of Neonatology,Addin Medical college Hospital, Dhaka.

2. Professor Zabrul S.M. Haque Professor \& Director Pediatrics and Neonatal ICU, Ad-din Medical College Hospital, Dhaka

3. Dr. Md. Abdul Mannan Assistant professor, Department of Neonatology, Addin Medical college Hospital, Dhaka

4. Dr. Morsheda Akhter Associate professor, Department of Microbiology, Addin Medical college Hospital, Dhaka

5. Dr. Sabina Yasmin Indoor Medical Officer, Department of Neonatology, Ad-din Medical college Hospital

6. Dr. Shirin Akhter Indoor Medical Officer, Department of Neonatology, Ad-din Medical college Hospital, Dhaka.

7. Dr. Abu Mohammad Talukder Associate professor, Department of Pediatrics, Dhaka Community Medical college Hospital, Dhaka.

8. Dr. Sonjoy Kumar Dey Assistant Professor, Department of Neonatology, Bangabandhu Sheikh Mujib Medical University, Dhaka

* Address of correspondence

E. mail: njahan.jesy@gmail.com. Mobile.+8801757078207 
bacteremia (40\%), septic arthritis (5 10\%), and rarely omphalitis and osteomyelitis. The reported incidence of neonatal sepsis varies from 7 to 38 per 1000 live birth in Asia $^{9}$, from 6.5 to 23 per 1000 live birth in Africa ${ }^{10}$ and from 3.5 to 8.9 per 1000 live birth in South America and the Caribbean ${ }^{11,}{ }^{12}$. Rates reported in the United States and Australasia range from 6-9 per 1000 live birth ${ }^{13,14}$ and in Europe 0.3-3 per 1000 live birth ${ }^{15}$. In most developing countries, gram-negative bacteria remain the major cause of neonatal sepsis ${ }^{16}$, 17. These organisms have developed increased drug resistance over the last two decades $^{18}$. On the other hand Group B Streptococcus (GBS) has been the most frequent etiological agent of neonatal sepsis in developed countries, being responsible for high morbidity and mortality ${ }^{19}$. Since the spectrum of organisms that cause neonatal sepsis changes overtime and varies from region to region and hospital to hospital even in the same city/country, it is necessary to conduct periodic surveillance to access the changing pattern of organisms causing neonatal sepsis. Therefore knowledge of the pattern of bacterial isolates and their antimicrobial susceptibility pattern is useful for prompt treatment of patients. Although an extensive research is available worldwide ${ }^{2,18}$,

${ }^{20}$, very few reports are available on neonatal sepsis in Bangladesh. Considering this, the present study was undertaken to highlight the pattern of bacterial isolates responsible for early onset and late onset neonatal sepsis in hospital settings among neonates with clinical diagnosis of septicemia.

\section{Methods:}

A prospective descriptive study, over a period of 12 months (January to December 2011), a total of 1000 neonates ( 0 to 28 days of age) with suspected clinical diagnosis of septicemia admitted to Neonatal Intensive Care Unit (NICU) in Ad-din Medical College Hospital were investigated with the aim to detect bacterial pathogens responsible for early and late onset neonatal sepsis, gender frequency and mortality rate. Neonates were suspected having sepsis if they presented with one of the following signs or symptoms: fever (temp. $>38^{\circ} \mathrm{C}$ ), Hypothermia (Temp. < $36^{\circ} \mathrm{C}$ ), decreased sucking, poor sucking or not sucking, lethargy, irritability, seizure, apnea, cough, respiratory distress, abdominal distention or those who were born to mothers with potential risk factors for infection. Risk factors in the mother included prolonged rupture of membranes (PROM) of $>12$ hours, fever, urinary tract infection, chorioamnionitis and meconium stained amniotic fluid. Both premature and full terms were included and all must have a positive blood culture. Neonates who had clinical picture of sepsis without positive blood culture were excluded. Written informed consents were obtained from the parents/guardians, and were investigated for bacterial etiologic agents. Demographic, clinical and other relevant data were obtained by attending pediatrician/s and were transferred to the questionnaire prepared for this study. Target neonates were divided into two groups according to the timing of clinical signs as early onset (clinical signs of sepsis from birth to 7 days old) and late onset (clinical signs of sepsis from 8 to 28 days old) infections. Neonates were also classified into normal birth weight (birth weight $>2500 \mathrm{gm}$ ) or low birth weight (birth weight $<2500 \mathrm{gm})$. According to gestational age they were again divided into term (gestational age >37 weeks) and preterm (gestational age $<37$ weeks) baby. Blood culture, chest X-ray and laboratory tests including complete blood count (CBC), blood sugar (BS) and $S$. electrolytes were performed for all patients. Using aseptic technique by applying Povidone iodine and $70 \%$ alcohol at the site of vein puncture, $2 \mathrm{ml}$ venous blood was drawn from the peripheral vein by the attending nurse and then the blood was inoculated into a blood culture bottle containing Tryptone Soy Broth (TSB) and Brain Heart infusion Broth. The specimens were transported immediately to microbiological laboratory and incubated for one week in $37^{\circ} \mathrm{C}$ and were daily checked for evidence of bacterial growth. For positive broth cultures, subcultures were made on solid media (Blood agar and McConkey agar) and were incubated in $37^{\circ} \mathrm{C}$ for 24 to 48 hours. The grown bacteria were identified by colony morphology, gram stain and biochemical tests. Antimicrobial susceptibility testing was performed for all blood culture isolates according to the criteria of the National Committee for Clinical Laboratory Standards by disk diffusion method. Data 
analysis was done using statistical package for social sciences (SPSS) software version 14.0.

\section{Results:}

During the study period 1000 samples were collected from the neonates admitted in the NICU. Among them Positive blood cultures were obtained for 87 neonates $(8.7 \%)$. Of these, $46(52.8 \%)$ were preterm and 41 (47.1\%) were term, 53(60.9\%) neonates were with low birth weight and 34 newborns (39\%) with normal birth weight. There were 55 (63.2\%) male and 32 (36.8\%) female, with the male to female ratio of $1.7: 1$. Sixty six $(75.9 \%)$ had sepsis with gram negative bacteria and $21(21.4 \%)$ with gram positive bacteria. Ratio of gram negative organisms (75.9\%) to gram positive organisms (24.1\%) was 3.1:1.
The most common isolated gram negative bacteria were Acinetobacter (34.4\%), Pseudomonas spp. (21.8\%), Klebsiella pneumoniae (6.9\%), Moraxella (6.9\%), Enterobacter (3.4\%), and E.coli (2.2\%). Coagulase negative staphylococci (CONS) were the most isolated prevalent gram positive bacteria (18.4\%). Among neonates with sepsis, 66 patients $(75.8 \%)$ had early onset and $21(24.1 \%)$ had late-onset neonatal sepsis. Acinetobacter (34.47\%) was the most common pathogen in both early- onset $(24.13 \%)$ and late-onset (10.34\%) sepsis. Pseudomonas (21.83\%) was the second most common organism and was more common in early onset $(19.54 \%)$ neonatal sepsis. Death was low in this study $5(5.7 \%)$. Pseudomonas contributes majority of death $3(60 \%)$.

Table 1: Type and number of bacterial isolates in neonates with sepsis based on the sepsis onset \& mortality

\begin{tabular}{|l|l|l|l|l|}
\hline \multirow{2}{*}{ Microorganism } & \multicolumn{2}{|c|}{ Type of sepsis } & Total (\%) & $\begin{array}{c}\text { Death } \\
(\%)\end{array}$ \\
\cline { 2 - 4 } & Early-onset (\%) & Late-onset \%) & & $1(1.15)$ \\
\hline Acinetobacter & $21(24.13)$ & $9(10.34)$ & $30(34.47)$ & $3(3.44)$ \\
\hline Kseudomonas & $17(19.54)$ & $2(2.29)$ & $19(21.83)$ & \\
\hline E. Coli & $5(5.74)$ & $1(1.14)$ & $6(6.88)$ & \\
\hline Enterobacter & $1(1.14)$ & $1(1.14)$ & $2(2.28)$ & \\
\hline CONS & $1(1.14)$ & $2(2.29)$ & $3(3.43)$ & \\
\hline Staphylococcus aureus & $11(12.64)$ & $5(5.74)$ & $16(18.38)$ & \\
\hline Enterococci & $4(4.59)$ & 0 & $4(4.59)$ & \\
\hline Moraxella & $1(1.14)$ & 0 & $1(1.14)$ & \\
\hline Total & $5(5.74)$ & $1(1.14)$ & $6(6.88)$ & $1(1.15)$ \\
\hline
\end{tabular}

Table 2: Characteristics of gestational age and birth weight in neonatal sepsis according to causative organism:

\begin{tabular}{|c|c|c|c|c|c|c|c|c|c|}
\hline Features & $\begin{array}{l}\text { Acineto- } \\
\text { bacter }\end{array}$ & $\begin{array}{l}\text { Psedo } \\
\text { monas } \\
\text { aeruginosa }\end{array}$ & $\begin{array}{l}\text { Klebsiella } \\
\text { pneum. }\end{array}$ & E.Coli & $\begin{array}{l}\text { Mora } \\
\text { xella }\end{array}$ & CONS & $\begin{array}{l}\text { Staph } \\
\text { Aureus }\end{array}$ & Others & Total \\
\hline \multicolumn{10}{|c|}{ Gestational age } \\
\hline Term & $\begin{array}{c}9 \\
(10.34)\end{array}$ & $\begin{array}{c}9 \\
(10.34)\end{array}$ & $\begin{array}{c}2 \\
(2.29)\end{array}$ & $\begin{array}{c}2 \\
(2.29)\end{array}$ & $\begin{array}{c}4 \\
(4.59)\end{array}$ & $\begin{array}{c}5 \\
(5.74)\end{array}$ & $\begin{array}{c}2 \\
(2.29)\end{array}$ & $\begin{array}{c}2 \\
(2.29)\end{array}$ & $\begin{array}{c}35 \\
(40)\end{array}$ \\
\hline Preterm & $\begin{array}{c}21 \\
(24.13)\end{array}$ & $\begin{array}{c}10 \\
(11.49)\end{array}$ & $\begin{array}{c}4 \\
(4.59)\end{array}$ & $\begin{array}{c}0 \\
(0)\end{array}$ & $\begin{array}{c}2 \\
(2.29)\end{array}$ & $\begin{array}{c}11 \\
(12.64)\end{array}$ & $\begin{array}{c}2 \\
(2.29)\end{array}$ & $\begin{array}{c}2 \\
(2.29)\end{array}$ & $\begin{array}{c}52 \\
(60)\end{array}$ \\
\hline \multicolumn{10}{|l|}{ Birth weight } \\
\hline $\begin{array}{l}>2500 \mathrm{gm} \\
(\mathrm{AGA})\end{array}$ & $\begin{array}{l}8 \\
(9.19)\end{array}$ & $\begin{array}{l}8 \\
(9.19)\end{array}$ & $\begin{array}{l}0 \\
(0)\end{array}$ & $\begin{array}{l}2 \\
(2.29)\end{array}$ & $\begin{array}{l}3 \\
(3.44)\end{array}$ & $\begin{array}{l}8 \\
(9.19)\end{array}$ & $\begin{array}{l}1 \\
(1.49)\end{array}$ & $\begin{array}{l}2 \\
(2.29)\end{array}$ & $\begin{array}{l}32 \\
(36.78)\end{array}$ \\
\hline $\begin{array}{l}<2500 \mathrm{gm} \\
(\mathrm{LBW})\end{array}$ & $\begin{array}{l}22 \\
(25.28)\end{array}$ & $\begin{array}{l}11 \\
(12.64)\end{array}$ & $\begin{array}{l}6 \\
(6.89)\end{array}$ & $\begin{array}{l}0 \\
(0)\end{array}$ & $\begin{array}{l}3 \\
(3.44)\end{array}$ & $\begin{array}{l}8 \\
(9.19)\end{array}$ & $\begin{array}{l}3 \\
(3.44)\end{array}$ & $\begin{array}{l}2 \\
(2.29)\end{array}$ & \begin{tabular}{|l}
55 \\
$(63.22)$
\end{tabular} \\
\hline
\end{tabular}


CONS: Coagulase Negative Staphylococci, Staph: Staphylococcus, LBW: Low Birth weight,

AGA: Appropriate for Gestational age

Table 3: Treatment outcome (no. of cases) according to sex, gestational age, birth weight and type of sepsis

\begin{tabular}{|c|c|c|c|c|c|c|c|c|}
\hline \multirow{2}{*}{$\begin{array}{l}\text { Cate } \\
\text { Gory }\end{array}$} & \multirow{2}{*}{$\begin{array}{c}\text { Total no } \\
\text { of } \\
\text { cases }\end{array}$} & \multicolumn{2}{|c|}{ GA(wks) } & \multicolumn{2}{|c|}{ Wt(gm) } & \multirow[t]{2}{*}{ Male } & \multirow{2}{*}{$\begin{array}{c}\text { Femal } \\
\mathrm{e}\end{array}$} & \multirow[t]{2}{*}{ Mortality } \\
\hline & & $\begin{array}{c}\text { Term } \\
>37\end{array}$ & $\begin{array}{c}\text { Pre } \\
\text { term<37 }\end{array}$ & $\begin{array}{c}\text { AGA } \\
>2500\end{array}$ & LBW $<2500$ & & & \\
\hline $\begin{array}{l}\text { Early } \\
\text { onset }\end{array}$ & $\begin{array}{l}65 \\
(74.7)\end{array}$ & $\begin{array}{l}31 \\
(35.6)\end{array}$ & $\begin{array}{l}34 \\
(39)\end{array}$ & $\begin{array}{l}25 \\
(28.7)\end{array}$ & $\begin{array}{l}40 \\
(45.9)\end{array}$ & $\begin{array}{l}43 \\
(48.4)\end{array}$ & $\begin{array}{l}22 \\
(25.3)\end{array}$ & $\begin{array}{l}3 \\
(3.4)\end{array}$ \\
\hline $\begin{array}{l}\text { Late } \\
\text { onset }\end{array}$ & $\begin{array}{l}22 \\
(25.2)\end{array}$ & $\begin{array}{l}10 \\
(11)\end{array}$ & $\begin{array}{l}12 \\
(13.6)\end{array}$ & $\begin{array}{l}9 \\
(10.34)\end{array}$ & $\begin{array}{l}13 \\
(14.9)\end{array}$ & $\begin{array}{l}12 \\
(13.7)\end{array}$ & $\begin{array}{l}10 \\
(11.5)\end{array}$ & $\begin{array}{l}2 \\
(2.3)\end{array}$ \\
\hline Total & $\begin{array}{l}87 \\
(100)\end{array}$ & $\begin{array}{l}41 \\
(47.1)\end{array}$ & $\begin{array}{l}46 \\
(52.9)\end{array}$ & $\begin{array}{l}34 \\
(39.08)\end{array}$ & $\begin{array}{l}53 \\
(60.92)\end{array}$ & $\begin{array}{l}55 \\
(63.2)\end{array}$ & $\begin{array}{l}32 \\
(36.8)\end{array}$ & $\begin{array}{l}5 \\
(5.7)\end{array}$ \\
\hline
\end{tabular}

\section{Discussion:}

Neonatal sepsis is one of the leading causes of death among neonates in Bangladesh, other important causes being prematurity and low birth weight, birth asphyxia and hypothermia. In this study, prevalence of documented neonatal sepsis with positive culture was $8.7 \%$. The isolation rate of bacteria in this study is comparable to rates reported in Iran $(6.6 \%){ }^{21}$, Libya $(5.9 \%)^{22}$, Bahrain $(4.2 \%)^{23}$. Higher isolation rates were reported in Nigeria (45. 9\%) ${ }^{24}$, India (52.6\%) ${ }_{25}$ and Pakistan $(54.0 \%)^{26}$. In the present study, early onset sepsis constituted more than two third of the cases, which is in agreement with the reports from other developing countries e.g. in Iran $(77.5 \%$ vs.22.5\%) ${ }^{21}$ and in a study of Bangladesh $(70.7 \% \text { vs. } 29.3 \%)^{27}$, but in contrast with reports from Saudi Arabia (39\% vs. $61 \%)^{28}$, Pakistan (42\% vs. $58 \%)^{26}$ and Libya (31 vs. $69 \%)^{22}$, where late onset sepsis is more common. The possible explanation for a higher frequency of EOS in this study might be the more referral of preterm labors and preterm newborns to our center. This study has shown male female ratio of 1.7:1 which is similar to earlier report ${ }^{29}$.
It is seen globally that overall ratio of gram negative organisms to gram positive organism is $2: 1^{30}$. In this study it was $3 \cdot 1: 1$. This finding is similar to that of other studies which showed that gram negative bacteria were responsible for most cases of neonatal sepsis $21,26,31,32$. Although some other studies found that gram positive bacteria were the commonest cause of neonatal sepsis ${ }^{12,16,33}$, while one study showed that the frequency of isolation of both gram positive and gram negatives was equal ${ }^{28}$. Among gram negatives organisms, most cases were due to Acinetobacter and Pseudomonas spp. and commonest gram positive organisms was Coagulase Negative Staphylococcus (CONS). Acinetobacter was the predominant organism for both early onset and late onset sepsis. Pseudomonas was the second most common organism isolated in this study. Studies from different countries report CONS as the predominant organisms in LOS ${ }^{33,34}$. However, in this study, Coagulase Negative Staphylococci (CONS) is the predominant gram positive organism in EONS. Among the originating cause of neonatal sepsis prematurity and Low birth weight was the 
leading cause of sepsis contributing about two third of EONS in this study. Generally the spectrum of organisms causing neonatal sepsis in this study is similar to other reports from developing countries, with gram negative bacteria being responsible in most cases. But the pattern of isolated organisms in our study slightly differs from the findings in a study in Iran $^{21}$ and India ${ }^{15}$ where Pseudomonas Aeruginosa was the most common cause of neonatal sepsis followed by Klebsiella spp. and E. coli. In similar studies from Bangladesh, Nepal and Pakistan, E. coli was the leading cause of neonatal sepsis followed by Klebsiella spp ${ }^{31,25}$. In other studies gram positive bacteria such as $\mathrm{S}$. Aureus and group B streptococcus (GBS) were found to be the most common isolates in neonatal septicemia ${ }^{12}$. Prior to antibiotic era, the mortality from septicemia was more than $90 \%$. In the present time mortality remains high, between $20 \%-40 \%{ }^{7}$. The mortality rate in this study was low (5.7\%) which may be due to presence of adequate supportive facilities in the study hospital, since this is a tertiary care hospital and NICU provide level 3 care and other logistic support. Most of the death occurred in this study were preterm, low birth weight and early onset sepsis. Pseudomonas was the main organism causing mortality.

\section{Conclusion:}

Acinetobacter, Pseudomonas spp. and Coagulase negative $\mathrm{S}$. Aureus were the most common organisms causing neonatal sepsis. Acinetobacter was more common in both early and late onset sepsis. Pseudomonas was significantly more common in early onset than in late onset sepsis. There was significant correlation between mortality rate and type of causative pathogen, gestational age, birth weight, onset of sepsis in this study. Different neonatal intensive care unit (NICU) show different epidemiological data for neonatal sepsis. So collection of up-to-date \& site specific data is mandatory for appropriate use of antibiotics.

\section{Acknowledgement:}

We are indebted to the all Resident Medical officer of NICU of Ad-din Medical College Hospital for the necessary support to conduct this study.

\section{References:}

1. Edwards MS . Postnatal infections. In : Fanaoff and Martins Neonatal-perinatal Medicine. $8^{\text {th }}$ ed . Philadelphia: Mosby Elsevier; 2006. p.791804.

2. Vergnano $S$, Sharland $M$, Kazembe $P$, Wansambo CM, Heath PT. Neonatal sepsis : an ernational perspective. Arch. Dis.Child. Fetal Neonatal 2005; 90:F220-F24.

3 Zupan J,Aahman E, Perinatal mortality for the 2000: estimates developed by WHO. Geneva: World Health Organization, 2005.

4. Stoll BJ. The global impact of neonatal infection. Clin Perinatol 1997;24:1-21.

5. Bang AT, Reddy HM, Deshmukh MD, Baitule $S B$, Bang RA. Neonatal and infantmortality in the ten years (1993 to 2003) of the Gadchiroli field trial: effect of home based neonatal care. $\mathrm{J}$ Perinatol 2005; 25 : S 92-107.

6. UNICEF. The State of World's Children 2012. $87-107$

7. National institute of population research and training (NIPORT), Mitra and associates, and ORC macro, Bangladesh Demographic and Health survey 2004. Dhaka Bangladesh and Calverton, Mayland [USA]: National institute of population research and training, Mitra and associates, and ORC macro;2005.

8. Kaftan H, Kinney JS. (1998) Early onset neonatal bacterial infections. Semin Perinatol 1998;22:15-24.

9. Lim NL, Wong YH, Boo NY, Kasim MS, Chor $C Y$. Bacteraemic infections in a neonatal intensive care unit: a nine months survey. Med J Malaysia 1995; 50:59 -63.

10. Airede Al. Neonatal septicaemia in an African city of high altitude. J Trop Pediatr 1992 ; 38:189-91.

11. Moreno MT, Vargas $S$, Poveda $R$, SáezLlorens $X$. Neonatal sepsis and Meningitis in developing Latin American. Paediatr Infect Dis J 1994; 13:516-20.

12. Robillard PY, Nabeth $P$, Hulsey TC, Sergent $M P$, Périanin J, Janky E. Neonatal bacterial septicaemia in a tropical area. Four-year experiences in Guadeloupe (French West Indies). Acta Paediatr 1993 82:687 -9. 
13. Hyde TB, Hilger TM, Reingold A, Farley MM, O'Brien $K L$, Schuchat $A$. Trends in incidence and antimicrobial resistance of early-onset sepsis: population-based surveillance in San Francisco and Atlanta. Pediatrics 2002; 110:690 -5.

14. Heath PT, Nik Yusoff NK, Baker CJ. Neonatal meningitis, Arch Dis Child 2003; 88:173 -8.

15. Vesikari $T$, Janas $M$, Grönroos $P$, Tuppurainen $N$, Renlund $M$, Kero $P$, Koivisto $M$, Kunnas $M$, Heinonen K, Nyman R. Neonatal septicaemia. Arch Dis Child 1985; 60:542-6

16. Anwer SK, Mustafa S, Pariyani S, Ashraf S, Taufiq KM. Neonatal sepsis: an etiologic study. J Pak Med Assoc 2000;50:91-94.

17. Joshi SG, Ghole VS, Niphadkar KB. Neonatal gram negative bacteremia. Indian $\mathrm{J}$ Pediatr 2000; 67:27-32.

18. Bhutta ZA. Neonatal bacterial infections in developing countries: strategies for prevention. Semin Neonatol1999; 4:159-71.

19. Freedman RM, Ingram DL, Gross I, Ehrenkranz $R A$, Warshaw JB, Baltimore RS. A half century of neonatal sepsis at Yale. Am J Dis Child 1981;135:140-44.

20. Klein JO. From harmless commensal to invasive pathogen coagulase-negative staphylococci. N Engl J Med 1990; 323:339-40.

21. Movahedian AH, Moniri $R$, Mosayebi $Z$. Bacterial Culture of Neonatal Sepsis. Iranian J Publ Health 2006;35: 84-89.

22 Misallati $A$, el-Bargathy $S$, Shembesh $N$. Blood-culture-proven neonatal septicaemia: a review of 36 cases.East Mediterr Health $\mathrm{J}$ 2000; 6: 483-6.

23. Bindayna KM, Jamsheer A, Farid E, Botta GA. Neonatal sepsis 1991-2001: prevalent bacterial agents and antimicrobial susceptibilities in Bahrain. Med Princ Pract 2006;15:131-6.

24. Meremikwu MM, Nwachukwu CE, Asuquo AE, Okebe JU, Utsalo SJ. Bacterial isolates from blood cultures of children with suspected septicaemia in Calabar, Nigeria. BMC Infectious Disease 2005; 5:110-17.

25. Murty DS, Gyaneshwari M. Blood cultures in pediatric patients: a study of clinical impact. Indian J Med Microbiol 2007;25:220-4.

26. Aftab $R$, Iqbal I. Bacteriological agents of neonatal sepsis in NICU at Nishtar Hospital Multan. J Coll Physicians Surg Pak 2006; 16:216-9.

27. Rasul $\mathrm{CH}$, Hassan MA, Habibullah $M$. Neonatal sepsis and use of antibiotic in tertiary care hospital. Pak J Med Sci 2007; 23:78-81.

28. Umran K, Twum-Danso K. A case control study of neonatal sepsis: Experience from Saudi Arabia.J Trop Pediatr 1997; 43:84-8.

29. Jain NK, Jain VM, Maheshwari S. Clinical profile of neonatal sepsis. Kathmandu Univ Med J 2003; 1(2):117-20.
30. Ganatra HA, Stoll BJ, Zaidi AKM. International perspective on early -onset neonatal sepsis. Clin Perinatol 2010; 37:501-23

31. Ahmed AS, Chowdhury MA, Hoque $M$, Darmstadt GL. Clinical and bacteriological profile of neonatal septicemia in a tertiary level pediatric hospital in Bangladesh. Indian Pediatr 2002; 39:1034-9.

32. Rahman S, Hameed A, Roghani MT, Ullah Z. Multi-drug resistant neonatal sepsis in Peshawar, Pakistan. Arch Dis Child Fetal Neonatal 2002; 87: F52-F54.

33. Munson DP, Thompson TR, Johnson DE, Rhame FS, VanDrunen $N$, Ferrieri $P$. Coagulase-negative staphylococcal septicemia: experience in a newborn intensive care unit.J Pediatr 1982; 101:602-5.

34. Baumgart S, Hall SE, Campos JM, Polin RA. Sepsis with coagulase-negative staphylococci in critically ill newborns. Am J Dis Child 1983;137:461 